\title{
Ciência, Políticas Públicas e Inclusão Social: Debates sobre Células-Tronco no Brasil e no Reino Unido*
}

\section{Liliana Acero}

Professora visitante no Instituto de Economia (IE), do Programa de Pós-Graduação em Políticas Públicas, Estratégias e Desenvolvimento (PPED) da Universidade Federal do Rio de Janeiro (UFRJ) e professora associada na Pós-Graduação em Gênero, Sociedade e Políticas (PRIGEPP), da Faculdade Latinoamericana de Ciências Sociais (Flacso).

E-mail: lilianaacer02009@gmail.com

\section{INTRODUÇÃO}

$\mathrm{O}$

objetivo principal deste artigo é examinar alguns dos recursos retóricos e das estratégias utilizadas durante os debates acerca das pesquisas com células-tronco adultas (PCTA) e das pesquisas com células-tronco embrionárias (PCTE) no Brasil, e desenvolver apenas algumas comparações com aspectos selecionados do debate no Reino Unido e relevantes para o Brasil. O caso britânico foi selecionado frente a outros países desenvolvidos, uma vez que se trata de um líder no campo e por ter desenvolvido um marco regulatório e bioético pioneiro e centralizado em nível público, além de algumas formas de engajamento público e de inclusão social nesta área, interessantes para a reflexão local e para comparações com as tendências brasileiras dominantes.

\footnotetext{
* Este artigo baseia-se em resultados parciais da pesquisa coordenada pela autora intitulada: Desenvolvimento de Capacidades para a Governança: Visões Sociais e o Debate sobre Células-Tronco no Brasil, bolsa FAPERJ Pesquisador Visitante (2009-2010) e CNPq Universal (2010-2011), (sitio web do projeto www.govcel.com.br), Programa de Políticas Públicas, Estratégias e Desenvolvimento (PPED), Instituto de Economia, da Universidade Federal do Rio de Janeiro (UFRJ). Agradeço à equipe de pesquisa, em especial à professora Lia Hasenclever do Instituto de Economia, UFRJ, pelos comentários em versões preliminares deste artigo e à estudante do PPED, Helena Klein, por sua colaboração na pesquisa.
}

DADOS - Revista de Ciências Sociais, Rio de Janeiro, vol. 53, nㄴ, 2010, pp. 855 a 887. 
Serão apresentados alguns temas centrais do debate brasileiro no período da aprovação da Lei de Biossegurança de 2005 (Lei no 11.105, 24/3/2005) e, mais especificamente, durante a Audiência Pública realizada na ocasião do julgamento da Ação Direta de Inconstitucionalidade (ADI no 3.510) pelo Supremo Tribunal Federal (STF), em 2008. (A ação tinha como objetivo principal a declaração de inconstitucionalidade da referida lei). Em seguida, estes serão comparados brevemente com algumas das posições no debate Parlamentar para a aprovação da Ata da Human Fertilisation and Embryology Authority (HFEA) de 1990, no Reino Unido, e durante as suas reformas mais recentes.

A análise atual está centrada no que Mulkay (1993:723) denomina "regularidades discursivas" para: mapear as fronteiras e os contornos do debate, indicar as principais convergências e divergências entre as posições de setores em oposição, os recursos utilizados por atores e agentes sociais pró e contra a PCT e as estratégias e táticas utilizadas para a opinião pública. Rastreiam-se as afirmações típicas mobilizadas durante as discussões, que refletem temas, ideias e pressupostos recorrentes. $\mathrm{O}$ texto não analisa in extenso as diferenças nas matrizes religiosas entre os dois países, já que estas mereceriam um tratamento específico e diferenciado (ver, por exemplo, Luna, 2008) e considera-se que as matrizes constituem um elemento importante dentro da cultura política (Jasanoff, 2004), sendo esta última afirmação um conceito mais geral e objeto mais específico desta análise. Pretende-se, no artigo, descrever cenários das retóricas gerais e práticas culturalmente diferenciadas em forma e conteúdo e estabelecer alguns paralelos entre os discursos e a legislação resultante ${ }^{1}$.

\section{A LEI DE BIOSSEGURANÇA DE 2005, NO BRASIL: PRIMEIROS MOMENTOS}

Existiram vários momentos cruciais nas múltiplas negociações, no Brasil, desde a aprovação da Lei de Biossegurança de 1995 (Lei no 8.974) até a etapa de aprovação da nova Lei (Lei no 11.105 , de $24 / 3 / 2005$ ), e nos debates relacionados que ocorreram até 2008. O processo de mudança legislativa incluiu os seguintes eventos: a aprovação da Lei original de 1995; a formação da Comissão Técnica Nacional de Biossegurança (CTNBIO); as contestações jurídicas às decisões desta Comissão relativas aos cultivos transgênicos; o primeiro Anteprojeto de Reforma da Lei de 1995, de 2003; a aprovação inicial, em 2005, da nova Lei; a Ação Direta de Inconstitucionalidade (ADI no 3.510) - ime- 
diatamente posterior - e a confirmação da constitucionalidade da mesma, em 2008.

Durante este longo percurso, os pareceres sobre biossegurança, no Congresso e na sociedade, foram mudando significativamente. O clima social local na relação Ciência/Medicina/Sociedade, no tocante às temáticas de saúde pública e outras associadas, também diferia, em 2008, daquele predominante em 1995. Num primeiro momento (1997-2003), a aprovação legal da comercialização de cultivos e alimentos transgênicos e, em particular, a importação e comercialização da soja transgênica Roundup Ready da Monsanto, resistente a algumas variedades de herbicidas, e o crescimento dos cultivos clandestinos no Rio Grande do Sul, se constituíram numa preocupação social central. O período de incerteza e ausência de marco regulatório facilitou às grandes empresas da agroindústria a comercialização ilegal dos Organismos Geneticamente Modificados (OGM), em especial da soja, do algodão e do milho, práticas frequentes até a posse do novo governo.

Por outro lado, o início da PCT, no nível nacional, se deu no ano de 1999, com promessas de resultados encorajadores em alguns campos da medicina. Nesse momento, a comunidade científica brasileira já requeria o desenvolvimento da experimentação com $\mathrm{PCTE}^{2}$. No Brasil, não existia ainda, - como não existe até a presente data -, legislação federal específica que regulasse o uso de embriões humanos em pesquisa, nem na reprodução assistida, sendo que esta última se desenvolveu sistematicamente desde os anos 1980 (Acero, 2007; Corrêa, 2001; Diniz e Gomes Costa, 2007). A referência à PCTE, no novo Anteprojeto de Reforma de Lei de Biossegurança de 2003, significava uma oportunidade de negociação das condições para sua liberação (Cesarino, 2007; Diniz e Avelino, 2009; Luna, 2007a; 2007b).

O contexto geral se mostrava positivo para o desenvolvimento de inovações em saúde, tendo em vista as repercussões sociais favoráveis da nova Constituição de 1988 e da criação do Sistema Único de Saúde (SUS). Até então, a relação Ciência/Medicina/Sociedade parecia transitar com relativa confiança, apesar de existirem controvérsias em alguns focos associados a: falhas na implementação e eficiência do SUS, legalização potencial do aborto e ineficácia na prevenção e no tratamento do HIV / AIDS.

Durante as negociações anteriores à aprovação da nova Lei, ainda se manteve a proibição da PCTE da Lei de Biossegurança de 1995, que só 
foi retirada quando o Anteprojeto de Lei de 2003 foi encaminhado à Câmara dos Deputados. Este tempo se caracterizou por um intenso debate social sobre os cultivos e alimentos transgênicos dentro dos Ministérios. No período 2003-2005, o centro do debate mudou dos transgênicos à PCTE, tanto na Câmara dos Deputados como na opinião pública. Neste segundo momento, o grupo opositor, maioria em número e influência política, teve uma reação contundente contra a liberação proposta. Agrupados na Bancada Católica e na Frente Parlamentar Evangélica (FPE), estabeleceram um acordo para modificar sua primeira formulação. Seus argumentos para a proibição da PCTE se baseavam no fato de que o início da vida humana se daria com a fecundação e a concepção, segundo dogma religioso. Porém, somente durante a tramitação desta Lei no Senado, num terceiro momento do debate, a posição sobre os embriões para pesquisa se tornaria mais clara.

\section{Lobbies Prévios e Construção de Demanda}

Frente à volta da proibição do uso de embriões em pesquisa realmente começou a se articular o lobby pró-pesquisa (pró-PCTE) para reverter esta decisão (Cesarino, 2007). O lobby contra-pesquisa (contra-PCTE) já estava bastante articulado desde momentos prévios, em especial dentro da Câmara de Deputados, e se fortaleceu ainda mais com a inclusão de grupos antiaborto. O lobby pró-PCTE estava composto principalmente por cientistas e por grupos de doentes e pacientes com incapacidades, potencialmente tratáveis pelas futuras terapias celulares, e seus familiares, muitos deles, agrupados na principal organização de pacientes da sociedade civil, criada, principalmente, para esse fim: Movimento em Prol da Vida (Movitae). O grupo defensor das PCTE estava aliado com o lobby pró-transgênicos, já que compartilhava a estratégia para a aprovação conjunta de ambos os tipos de regulação (Scavone, 2008).

Os cientistas pró-PCTE, convidados para participar da Audiência Pública, no Senado, em 2004, recorreram a uma estratégia pragmática, concentrados em informar sobre os detalhes técnicos destas pesquisas e fundamentar sua posição favorável "na oportunidade de aproveitamento humanitário" de embriões excedentes, congelados nas clínicas de fertilização assistida, e inviáveis para fertilização. Estes foram estimados entre 20 e 30 mil, o que representou uma significativa superestimação. O descarte dos embriões congelados nas clínicas foi apresentado como inevitável, cotidiano e preexistente, e o valor da vida das víti- 
mas tratáveis com PCTE foi hierarquizado em face dos embriões congelados (Cesarino, 2007; Luna, 2007a; 2007b; Tait Lima, 2009). Os cientistas pró-PCTE também defenderam a importância de realizar essas pesquisas para que o Brasil "não ficasse atrás" na corrida biotecnológica. Os debates evitaram toda a discussão, conceitual e ética, sobre o embrião e o começo da vida humana e omitiram qualquer menção a técnicas potencialmente mais polêmicas no nível ético, como a clonagem terapêutica (SNCT), para produzir embriões exclusivamente com fins de pesquisa. Na última votação, em março de 2005, muitos dos deputados cristãos já eram favoráveis à liberação da PCTE.

O debate social e legislativo colaborou, indiretamente, na construção de uma demanda social para a terapia celular. Esta apresenta um lado positivo e outro negativo. Por um lado, incentivou a difusão social e específica, para pacientes potenciais, seus familiares e redes, da existência e das características da PCT. Mas, também constituiu uma estratégia de significativo risco para cientistas, usuários e formuladores de políticas, cujas consequências podem ser observadas até a atualidade ${ }^{3}$. A omissão durante o debate do prazo em que tais promessas poderiam se realizar, as dificuldades reais para gerar resultados positivos neste campo novo e as dificuldades para a implementação das futuras terapias levaram, inevitavelmente, a um aumento das expectativas por parte da opinião pública em geral.

A demanda social, então construída, ainda exerce uma pressão desmedida sobre os mesmos sujeitos que proporcionaram seu conhecimento e experiência para a aprovação da pesquisa. A necessidade de resultados rápidos poderia comprometer a qualidade da pesquisa e a segurança, eficácia e eficiência das potenciais terapias. A frustração de expectativas sociais, por sua vez, poderia repercutir negativamente, tanto na confiança da população no setor médico-científico, quanto nos responsáveis pelas políticas públicas que apóiam e financiam a área. Estes processos de geração de expectativas para o futuro, de construção de uma demanda virtual, não são exclusivos do caso brasileiro, estando presentes em outros debates semelhantes, fenômeno que tem sido caracterizado como hype baseado no hope das pessoas ${ }^{4}$ (Martin, Brown e Turner, 2008).

A discussão sobre PCTE, até certo ponto, esteve permeada por um discurso neutro e pela defesa de uma autoridade técnico-científica - como excludente de outras formas de conhecimento -, e por um papel de li- 
derança atribuída ao Brasil. Mas, a retórica sobre a competitividade nacional não ocupou, nesse momento, um lugar tão predominante, em parte por se relacionar mais diretamente à saúde do que aos transgênicos (Tait Luna, 2009).

\section{AUDIÊNCIA PÚBLICA BRASILEIRA PARA A ADI Nㅜํํ.510}

Pouco tempo depois de aprovada a nova Lei, já em maio de 2005, a Procuradoria Geral da República entrou com uma Ação Direta de Inconstitucionalidade (ADI no 3.510) perante o STF, contra o artigo $5^{\circ}$ da Lei, que estabelece as condições para a realização da PCTE. Argumentou que este artigo infringia direitos constitucionais, baseando-se na tese de que "a vida humana acontece desde o momento da fertilização". Durante dois anos, as pesquisas nesta área continuaram de forma intermitente e com pouco apoio financeiro público, desenvolvendo-se num contexto de grande incerteza.

\section{Convocatória, Mecanismos e Funcionamento}

OSTF convocou uma Audiência Pública, a primeira da sua história, realizada no dia 24 de abril de 2007, para "ouvir depoimentos de pessoas com experiência e autoridade", e para esclarecer as dúvidas dos ministros. Como objetivo tácito, tentava-se proporcionar maior legitimidade às decisões. Os 22 especialistas expositores, divididos uniformemente em "dois blocos de opinião bem caracterizados": um contra e outro favorável ${ }^{5}$, contavam, cada um, com 20 minutos de exposição (STF, Transcrição da Audiência Pública para a Ação Direta de Inconstitucionalidade (TAP-ADI), 2008). Não houve nenhum espaço para o debate depois de cada apresentação, nem mesmo depois das intervenções de cada bloco. A discussão de ideias, visões e posições foi explicitamente desalentada, ou seja, impedindo-se a prática que define um verdadeiro debate.

Apesar de o STF ter declarado seu objetivo de propiciar uma participação maior da sociedade civil no recinto, esta correspondeu principalmente a alguns setores da comunidade científica ${ }^{6}$. A verdadeira participação da sociedade civil ocorreu através da sua presença em momentos prévios à própria Audiência, com seu traslado a Brasília e seu acampamento em frente ao Senado, através de publicações em jornais, revistas e sítios da internet de organizações específicas e de reporta- 
Ciência, Políticas Públicas e Inclusão Social: Debates sobre Células-Tronco...

gens televisivas de pacientes/familiares, juristas e cientistas (Acero, no prelo).

Alguns ministros caracterizaram a Audiência no STF como:

[...] uma Casa do Povo, tal qual o Parlamento. Um lugar onde os diversos anseios sociais e o pluralismo político, ético e religioso encontram guarida nos debates [...]. As Audiências Públicas [...] fazem desta Corte também um espaço democrático. Um espaço aberto à reflexão e à argumentação jurídica e moral, com ampla repercussão na coletividade e nas instituições democráticas (voto do ministro Gilmar Mendes, STF, TAP-ADI, 2008b:4).

[...] "uma discussão tão vívida, tão copiosa" e "um mecanismo de democracia participativa ou democracia direta" [...] Metaforicamente, democracia é isso mesmo, é prestigiar as bases, deslocando quem está na plateia, habitualmente, para o palco das decisões coletivas (voto do ministro Carlos Britto, STF, TAP-ADI, 2008b:215).

As formas seletivas de convocatória, o caráter não interdisciplinar, restrito a um setor profissional e a um só setor social-, e a forma de condução, que omitiu todo intercâmbio produtivo de ideias, perguntas e questionamentos não colocariam esta Audiência Pública num exemplo de democracia direta, - sem tirar-lhe seu mérito como processo educativo e ilustrativo. $\mathrm{O}$ "palco das decisões coletivas" foi ocupado pelos ministros, como apoio de um grupo epistêmico da comunidade científica. Tanto as inquietudes expostas após as apresentações dos cientistas pelos ministros, como as respostas aludem, principal ou indiretamente, a definições contrastantes da vida humana e do status do embrião.

\section{Definições da Vida Humana e da Ciência}

Na ADI e na Audiência Pública retornam com maior intensidade as discussões acerca das diversas posições ontológicas dos atores sociais sobre o começo da vida, da vida humana e sobre o status do embrião. Estas posições refletem as diversas "epistemologias cívicas"7 da cultura em que se desenvolve o debate, como analisado nos casos de outros países por Jasanoff (2005), autora que investiga o papel das culturas políticas na definição das políticas científicas. No contexto nacional, refletem uma cultura em transição para uma democracia mais inclusiva, a qual lida com os assuntos bioéticos de modo ambivalente, entre 
uma centralização em instituições pertinentes e uma descentralização para a aplicação dos princípios gerais ${ }^{8}$.

As aproximações e definições apresentadas, em termos de forma e conteúdo, mostram tanto visões divergentes sobre a PCTE, bem como são expressão de um conjunto inter-relacionado de pressupostos de background dos representantes. Estes, por sua vez, se constroem seguindo discursos socioculturais preexistentes, em sua maioria em conflito, mas, às vezes, convergentes.

Durante as exposições, frequentemente, os significados diferenciais atribuídos à vida humana se mascaram dentro da polaridade "Boa Ciência/Má Ciência", numa tentativa de construção de novas fronteiras dentro do campo de pesquisa com CT. Por exemplo, a respeito do marco dos três anos de congelamento de embriões fertilizados in-vitro para seu uso em pesquisa, cada bloco apresentou respostas diferentes para o traçado de fronteiras: a decisão dos progenitores versus o direito do embrião. O bloco pró-PCTE argumentou que tinha sido necessário estipular na Lei, por motivos jurídicos, um prazo para o casal de eventuais doadores tomar a decisão com segurança. Para o grupo opositor, a Lei tratou de evitar a criação de embriões exclusivos para pesquisa, porque isto, "abriria campo para o comércio de embriões e para uma série de fraudes" (Lenice Aparecida Martins Garcia, STF, TAP-ADI, 2008a:221).

O bloco pró-PCTE defendeu a definição de embrião inviável presente no artigo 3으, XIII, do Decreto no 5.591, de 2005, que regulamenta a Lei aprovada, como aquele com alterações genéticas comprovadas por diagnóstico pré-implantatório. O bloco contra-PCTE tentou fazer prevalecer o direito do embrião sobre o dos progenitores e uma concepção de natureza intocada pela Cultura, como base da Ciência; contrária às concepções contemporâneas sobre o fato científico e a co-construção Ciência/Cultura nos laboratórios (Latour e Woolgar, 1978).

Além disso, ambos os grupos manifestam suspeitas sobre os dados, evidências e formas de produzir Ciência no campo contrário. O bloco contra-PCTE fundamenta seus argumentos basicamente nas definições sobre o princípio da vida humana, que argumentam serem "unânimes" nos livros de Biologia "dos últimos cem anos". No bloco pró-PCTE, se expressa outra visão e hierarquia da vida, contraditoriamente, às vezes, o embrião passa a ser sujeito de suas decisões. "Estamos defendendo que, da mesma maneira que um indivíduo em morte 
cerebral doa órgãos, um embrião congelado pode doar suas células" (Mayana Zatz, STF, TAP-ADI, 2008a:13). O embrião aparece como, "uma vida que vale a pena sacrificar em prol de outras vidas". Contrapõe-se o conceito de vida do embrião e do ser humano ao conceito de vida em geral e a vida humana é caracterizada como relacional, gradual e evolutiva, desde a interação embrião-útero. O grupo pró-CTE apresentou, também, uma hierarquia de embriões com e sem vida útil, baseando-se em práticas já existentes das clínicas de fertilização, sendo a última uma estratégia interpretativa recorrente para fundamentar a realização de PCTE (ver, por exemplo, Franklin, Lury eStacey, 2000).

O bloco contra-PCTE tentou desmentir a posição de seus adversários, com respeito à diminuição da viabilidade dos embriões congelados para a reprodução humana, através de referências reiteradas a exemplos de crianças brasileiras, nascidas após 6 a 12 anos do congelamento do embrião (Alice Teixeira Ferreira, STF, TAP-ADI, 2008a:76; Rodolfo Acatauassú, STF, TAP-ADI, 2008a:134, entre outros). Argumentou-se que a divisão de embriões entre viáveis e inviáveis levaria também a uma classificação inapropriada entre tipos de pessoas: normais, adequadas ou inadequadas (Lenise Aparecida Martins Garcia, STF, TAD-ADI, 2008a:61).

A preocupação mais geral do grupo defensor consistiu em, sistematicamente, diferenciar embriões fecundáveis daqueles, ou daquelas células, que servem e/ou se utilizariam apenas para pesquisa. No entanto, durante o debate a noção de pré-embrião, conceito cunhado na Inglaterra (Warnock, 1985) e adotado pela Fundação Europeia da Ciência, que costuma fundamentar a visão pró- $\mathrm{PCTE}^{9}$, quase não se utilizou como estratégia discursiva.

Existe internacionalmente uma mudança paradigmática entre uma percepção social que considera o embrião como a unidade inicial de vida humana e aquela que atribui igual posição à CTE, com sua capacidade de gerar vida, como uma metonímia da vida e/ou como a vida mesma (Keller, 1995). Esta transformação muitas vezes reflete tanto lutas políticas sobre as definições das novas práticas, como transformações mais amplas introduzidas pela mesma nova genética: o momento histórico e o grau dessa transformação na sociedade analisada.

No Brasil, esta tendência de mudança parece ser ainda incompleta e incipiente, sendo que a principal polaridade expressada é entre o embrião como unidade inicial de vida humana e os embriões fecundá- 
veis/não fecundáveis. A perspectiva que considera a CTE unidade original da vida ainda suscita um grau marcado de oposição no posicionamento, por exemplo, de ambos os blocos e da sociedade mais ampla. Estas posições, de modo implícito, têm origem em crenças religiosas e/ou morais, principalmente católicas, professadas ativamente ou adquiridas por educação e influência cultural e dominantes na sociedade (Luna, 2008).

\section{Células-Tronco Adultas (CTA) versus Células-Tronco Embrionárias (CTE)}

Houve, durante o debate, divergências importantes entre os defensores de ambos os tipos de pesquisa, com CTA e com CTE, em relação a aspectos técnicos e éticos. No entanto, estas diferenças não refletiram uma rivalidade intensa entre comunidades científicas/epistêmicas bem demarcadas, como é o caso em outros países (Prainsack, Geesink e Franklin, 2008), provavelmente, devido à menor quantidade de pesquisadores dedicados à PCTE no Brasil, à maior colaboração no interior da área e ao fato de que esta tende a se definir ainda, conjuntamente, como uma nova comunidade epistêmica em formação. A maior polarização, no Brasil, manteve-se entre blocos.

Representantes da pesquisa e das terapias com CTA formavam parte de ambos os blocos, mas com posições diferentes. No bloco Pró-PCTE, mesmo os pesquisadores que só trabalham com CTA indicaram seu interesse profissional de incluir as CTE no seu trabalho futuramente ou defenderam a importância de continuar as pesquisas em nível nacional com CTE para a competitividade global do Brasil.

No bloco contra-PCTE, os pesquisadores especializados em CTA apresentaram sua oposição à CTE, basicamente, em função da sua concepção sobre a origem da vida humana, mas, também, se referindo à inexistência de aplicações terapêuticas contemporâneas com CTE em âmbito internacional (ver, por exemplo, Dalton Luiz de Paula Ramos, STF, TAP-ADI, 2008a:154). Outros cientistas/médicos disseram que só apoiariam a realização de PCTE em animais de laboratório.

Entre estes cientistas opositores, alguns enfatizaram os vários potenciais da PCTA nacional e internacional contemporânea e futura, listaram múltiplas aplicações novas em desenvolvimento e pretenderam demonstrar que as CTA, de diferentes modos, poderiam suprir algumas das vantagens atribuídas à CTE. Os expositores propuseram que fos- 
sem destinados maiores recursos e que fosse feito um esforço maior no desenvolvimento de inovações em CT com caráter embrionário derivável de fontes pouco pesquisadas até agora, como, por exemplo, do líquido amniótico.

Por contraste, o bloco dos pró-PCTE utilizou uma retórica discursiva de normalização da experimentação com CTE e, deste modo, reivindicou a superioridade de sua visão científica do mundo. Por exemplo, no que diz respeito ao campo das terapias potenciais, o apresentou como um terreno homogêneo e altamente promissor; uma fundamentação parcial, já que esta área de pesquisa se desenvolve de modo bastante fragmentado, tanto em âmbito nacional como internacional. Apoiaram a continuação simultânea de pesquisas em CTA e CTE com argumentos que incluíram: a menor plasticidade das CTA, sua incapacidade de substituir células mortas e regenerar órgãos e seu uso restrito a episódios agudos nas doenças. O grupo defensor também tentou oferecer algumas explicações, alternativas às do bloco opositor, sobre o papel que cumprem os embriões na PCTE. Por exemplo, mostrou como de $20 \mathrm{em}-$ briões, aproximadamente, se obtém apenas uma linhagem de CTE, sendo que esta é "estável e imortal", podendo ser utilizada num grande número de pesquisas. Também foi argumentado que o que se usa para pesquisa com embriões não é o próprio embrião e sim, "um aglomerado de células fora do útero" (Ricardo Ribeiro dos Santos, STF, TAP-ADI, 2008a:52) células extraídas do mesmo in-vitro, no pós-descongelamento. "Então, o que é estocado e usado é uma célula controlada e certificada geneticamente" (Ricardo Ribeiro dos Santos, STF, TAP-ADI, 2008a:53): uma visão ontológica de tipo utilitário, dentro de uma proposta pragmática, com um discurso de cunho industrialista.

A moralidade/imoralidade do uso de embriões para pesquisa também foi contrastada com a responsabilidade moral do cientista; duas estratégias discursivas em oposição sobre a noção de responsabilidade moral: "a responsabilidade está naquele que reconhece o potencial terapêutico das CTE, mas impede ou não incentiva o seu estudo. Nós não podemos nos eximir dessa responsabilidade de trabalho com as CTE" (Stevens Rehen, STF, TAP-ADI, 2008a:25). Em apenas um caso entre os defensores houve uma tentativa de se enquadrar o debate em outro tipo de normalização: a dos ensaios clínicos para novas terapias em geral (Deborah Diniz, STF, TAP-ADI, 2008a:257). Este argumento contrapõe, principalmente, as vicissitudes no avanço da Ciência e a sua ética em 
diferentes campos de conhecimento com os benefícios sociais e de saúde gerados.

\section{O Papel Social da Maternidade, a Infertilidade e o Aborto}

Durante a polêmica, o papel social atribuído à infertilidade, direta ou indiretamente, estaria significativa e culturalmente engenerado ${ }^{10}$ - salvo numa proposta -, embora devido a razões contrapostas. O bloco contra-PCTE considera de alguma maneira que todo embrião engendrado deveria ser implantado, a partir de uma concepção estereotipada e estigmatizada da maternidade, e utiliza retóricas interpretativas como: "Para se ter certeza de que um embrião é viável ou não, somente dando a oportunidade de implantá-lo. Tanto que, ao se implantarem vários embriões, nem todos são viáveis e se desenvolvem até o fim da gestação" (Lenice Aparecida Martins Garcia, STF, TAP-ADI, 2008a:215).

O bloco pró-CTE apresenta a doação de embriões congelados ou inviáveis como uma responsabilidade ética: “O que é eticamente correto? Preservar esses embriões congelados, mesmo sabendo que a probabilidade de gerar um ser humano é praticamente zero, ou doá-los para pesquisas que poderão resultar em futuros tratamentos?" (Mayana Zatz, STF, TAP-ADI, 2008a:13). A vida se hierarquiza em suas diferentes formas, priorizando-se os seres humanos vivos e em sofrimento e manifestando-se pressa de gerar curas. Mais ainda, o embrião se constitui em uma contribuição ao bem-estar das futuras gerações (Deborah Diniz, STF, TPA-ADI, 2008a:280).

Ambos os blocos convergem principalmente em ignorar e desconsiderar as percepções de eventuais doadores ou de eventuais progenitores, com uma exceção. Enquanto um bloco discursa sobre a obrigação destes progenitores de gerar bebês, o opositor enfatiza a responsabilidade social dos progenitores na doação para pesquisa, com a finalidade de viabilizar futuros tratamentos. Porém, em ambos os discursos contrapostos, tende a ser silenciada a visão de mundo dos sujeitos sociais que autorizariam ou não o uso de embriões.

Os cientistas assumem, de alguma maneira, que os pacientes de fertilização assistida concordam com a PCTE, sem contar com provas confiáveis a esse respeito. Calcula-se, como base para a PCTE, a quantidade de embriões congelados nas clínicas no momento da promulgação da Lei, sem que se soubesse, por exemplo, se, em que circunstâncias e con- 
dições e para que tipo de pesquisas seus progenitores concordariam em doá-las. Uma sub-representação e uma simplificação das perspectivas dos potenciais doadores permeiam os discursos de ambos os grupos.

Esta estratégia interpretativa atribui maior autoridade de fato para o processo de operacionalização das doações às clínicas de fertilização assistida do que aos progenitores, embora no campo daqueles contra-PCTE se efetuem críticas à fertilização assistida como lugar responsável inicialmente pela confusão atual sobre as definições do embrião. Por exemplo, a fertilização assistida, "coloca em questão uma escolha na civilização", e implica "numa passagem de um tipo de moralidade para outra", esta última correspondendo a um grande retrocesso civilizatório (Antonio José Eca, STF, TAP-ADI, 2008a:121). No campo pró-PCTE, as clínicas são consideradas responsáveis pela definição de uma hierarquia entre embriões, segundo sua viabilidade.

Em todos estes sentidos, se omite em ambos os blocos a discussão de dois aspectos importantes das doações: a) aquele sobre os processos potenciais de coerção na doação, exercida, eventualmente, desde a relação e interação médico-paciente, pesquisador-paciente, dentro e fora das clínicas de fertilização; b) a potencial arbitrariedade e as diferenças técnico-científicas para a gradação de embriões - por critérios diversos -, dentro das clínicas de fertilização assistida. Ademais, essas gradações não estão sujeitas a nenhuma padronização sistemática nem a sistema de controle regulatório, tanto dentro da sociedade brasileira como em outros países (Acero, 2007).

Somente num número pouco significativo de relatos, se menciona o uso de embriões congelados em pesquisas que tentem avançar na medicina reprodutiva - uma motivação muito ampla entre os doadores no Brasil e em outros países (Parry, 2006; Ferreira, Ávila e Portella, 2007)-, seu uso para procurar resolver a infertilidade e para a detecção de anormalidades embrionárias, antes da implantação.

Existe, no imaginário dos participantes, em especial, naqueles contra-PCTE, uma associação entre PCTE e aborto, sendo o último, proibido e penalizado no Brasil. Utilizam-se argumentos socioculturais preexistentes e transpostos de outros debates ${ }^{11}$ e já presentes durante a discussão original da Lei. Na maioria das argumentações contra-PCTE, foram realizadas referências diretas ou indiretas, analogias ou contrapontos com argumentos considerados inadequados para a 
defesa do aborto. Mostrou-se, por exemplo, que o feto pode sentir dor, que a mãe tem uma comunicação relacional precoce com o embrião/feto e que este influi, desde os primeiros dias sobre a produção hormonal e a psique da mãe (Lilian Pinero Eça, STF, TAP-ADI, 2008a:75).

Os estigmas sociais em jogo, então, relacionam-se principalmente com papéis sociais de gênero e com o lugar social das mulheres como mães e/ou doadoras. Secundariamente, se relacionam com o papel prioritário atribuído ao conhecimento científico e médico vis-à-vis outros saberes, inclusive, o conhecimento experiencial daqueles sujeitos sociais diretamente envolvidos numa prática: o dos progenitores de embriões eventualmente doáveis. A infertilidade constituiria agora uma fonte prioritária de materiais para pesquisa, sendo reposicionada dentro de preceitos sociais, culturalmente hegemônicos, para ambos os blocos. Os inférteis têm de priorizar o bem comum!

\section{A Competitividade Nacional}

A pressa para a aprovação da PCTE, associada à competitividade internacional do Brasil nesta área, ocupou algum lugar no debate, embora muito menos central, que aquele nas Câmaras dos Deputados e no Senado para a aprovação da Lei. Neste último caso, o debate relacionado à competitividade da PCT foi facilitado quiçá porque se defendia também a competitividade nacional do Brasil em transgênicos (Tait Lima, 2009).

Alguns pesquisadores pró-PCTE enfatizaram que as CTE já se utilizavam, em nível global, para gerar pesquisa em medicamentos e que estes avanços, em poucos anos, seriam transformados em patentes. Logo, se o Brasil não participasse da PCTE, os brasileiros, no futuro, teriam que comprar medicamentos de outros países para tratar suas doenças (Rosalia Otero, STF, TAP-ADI, 2008a:41). Defendeu-se também que a política de Ciência, Tecnologia e Inovação em Saúde, formulada com ampla participação social ${ }^{12}$, havia estabelecido como uma prioridade estratégica do país a área de Biotecnologia e, dentro da mesma, a pesquisa com células-tronco: “Entende-se que dessa forma o Brasil dispõe de possibilidades de desenvolver e manter atualizada a sua tecnologia de ponta, de manter atualizada a sua competência científica nacional, acompanhar as tendências mundiais e atender as necessidades de saúde" (Moisés Goldbaum, STF, TAP-ADI, 2008a:180). 
A principal temática em que existe uma convergência de opiniões entre blocos é sobre o papel internacional do Brasil com relação à PCTA, que aparece como um ícone de orgulho nacional. “O Brasil é o campeão do mundo com respeito à diversidade de aplicações clínicas alternativas utilizando CTA [...] é um dos principais países do mundo que curam seus pacientes com esta terapia" (Rogério Pazetti, STF, TAP-ADI, 2008a:159-160). Esta afirmação é retomada pelo bloco pró-PCTE, que conta com alguns desses cientistas pioneiros dentro de seu grupo. Porém, o bloco contra-PCTE utiliza esta mesma estratégia retórica para tentar excluir à PCTE.

Existem algumas omissões importantes, dentro das limitadas referências realizadas à competitividade brasileira com células-tronco, com uma escassez quase absoluta de menções a temas como: a possibilidade de acesso a estas terapias potenciais e seus possíveis custos, a futura relação entre o sistema científico e o de saúde com a indústria de biotecnologia, as eventuais discriminações étnicas e raciais que podem surgir $^{13}$, as consequências socioeconômicas do envelhecimento crescente da população nacional e a eventual utilização destas terapias para fins cosméticos (ver, por exemplo, Franklin e Kaftantzi, 2008).

\section{HUMAN FERTILISATION AND EMBRYOLOGY AUTHORITY ACT DE 1990 DO REINO UNIDO}

O Reino Unido foi pioneiro no reconhecimento da necessidade de regular as novas tecnologias reprodutivas (NTRs) e em estabelecer um corpo de legislação mais permissivo para a pesquisa com embriões humanos, transformando-se em um marco de referência internacional para a mesma. Durante os anos 1980, suscitou-se um amplo debate internacional para criar controles éticos para as NTRs que, até então, atuavam dentro de um vácuo legal, e definir o status jurídico e moral deste novo tipo de embriões.

Em 1982, o Governo criou uma Comissão Multidisciplinar com 16 representantes dirigida pela Baronesa Mary Warnock, reconhecida filósofa britânica da ética e participante ativa na política pública. Esta Comissão revisou uma ampla faixa de desenvolvimentos recentes na reprodução humana, a embriologia e a genética e suas implicações sociais, éticas, legais e de política pública e apresentou 64 recomendações (Warnock, 1985). 
As recomendações geraram controvérsias sociais importantes entre grupos religiosos e dentro da comunidade científica, predominando aquela correspondente ao estatuto do embrião extracorpóreo e dos limites para sua manipulação (Franklin, 1999). Frequentemente, considerou-se como arbitrário o limite de 14 dias para a experimentação com embriões, embora muitas vezes por motivos antitéticos. A polêmica social não resolvida atrasou o envio do Anteprojeto e este foi relatado com dois artigos alternativos, de modo a refletir a polaridade das posições sociais existentes: em um, a pesquisa com embriões era liberada; em outro, era proibida e criminalizada. O debate Parlamentar continuou entre 1988 e 1990, ano de aprovação da Ata de Fertilização Humana e Embriologia de $1990^{14}$, e teve duas etapas bem diferenciadas. Na primeira, o lobby antipesquisa e antiaborto produziu argumentos ontológicos radicais contra todo uso dos embriões, denominadas "crianças não nascidas; baseando-se em valores do direito à vida, à dignidade humana, à proteção ao inocente e à integridade familiar. Na segunda etapa, os cientistas pró-pesquisas organizaram-se no grupo de pressão PROGRESS (patient group) e projetaram uma imagem benéfica das pesquisas, principalmente em relação a sua contribuição para o controle de doenças genéticas. Um dos momentos de inflexão no debate parlamentar aconteceu após ter sido definida a noção de pré-embrião, o que permitiu ao lobby defensor se legitimar através do uso de uma linguagem embriológica e técnica. A Ata instituiu também uma entidade regulatória, a Autoridade em Fertilização Humana e Embriologia (HFEA), integrada por 21 membros, com autoridade para licenciar tratamentos, clínicas, bancos e diferentes tipos de pesquisa e para criar um Código de Prática.

Os grupos religiosos continuaram em diferentes graus de oposição. A Igreja Católica local adotou a posição geral Papal contra qualquer forma de interferência na criação da vida humana. Contudo, a Igreja Anglicana apoiou o uso responsável da genética para superar a infertilidade, mas foi contra o uso de gametas por doação e fez objeções sobre a criação de embriões extras durante a reprodução assistida ${ }^{15}$.

Em 1999, diante do crescente descontentamento público com a regulamentação dos avanços em genética, o governo fundou a Comissão de Genética Humana (HGC), incluindo Comitês Assessores sobre diagnósticos genéticos e sobre clonagem. Em 1991, já tinha sido fundado o Conselho de Bioética de Nuffield: grupo assessor independente e altamente influente, criado pela Fundação Nuffield, o Welcome Trust e o 
Conselho de Pesquisas Médicas (CMR). Com uma ampla representação de profissões, o Conselho tem por função assessorar tecnicamente o público em vários temas bioéticos e sua participação nos debates sobre genética tem sido proeminente.

\section{DA REFORMA DE 2001 À ATA DE 1990}

No Reino Unido, a PCTE se desenvolveu desde meados dos anos 1990. Mas, somente após o nascimento da ovelha Dolly, em 1997, o governo se interessou pela formulação de uma política pública específica (Parry, 2003, 2006). Entre 1997 e 2001, encomendou um relatório de consulta e estabeleceu um Comitê Assessor, a partir do qual desenvolveu um projeto de reforma da Ata original (HGAC/HFEA, 2008). A proposta acrescentou três novas categorias de pesquisa com embriões às cinco preexistentes. O regulamento tem permitido, desde 1990, a pesquisa com embriões em temas diretamente relacionados com a medicina reprodutiva: em contracepção, abortos espontâneos, infertilidade e para a detecção de anormalidades embrionárias antes da implantação. As categorias adicionadas tinham como objetivo aumentar o conhecimento sobre o desenvolvimento dos embriões e sobre doenças graves e permitir sua aplicação no desenvolvimento de terapias (HFEA, 2001).

Os debates foram muito amplos, dada a intensa preocupação social despertada pela possibilidade da clonagem humana. Muitas organizações de natureza científica publicaram informes e artigos na imprensa, se posicionando sobre o tema da clonagem, suas aplicações e implicações humanas. Desde o começo, a retórica discursiva estabelecia uma separação nítida entre a clonagem reprodutiva humana e a clonagem terapêutica. A primeira foi considerada antiética, insegura e ineficiente, "uma desvalorização e comoditização da vida humana", e recomendou-se sua proibição, através de legislação explícita. Pelo contrário, a segunda foi considerada com a potencialidade de contribuir com grandes benefícios médicos, como uma "técnica benevolente", que não apresentava nenhum novo desafio ético.

As ansiedades sociais pela clonagem humana coexistiram com um clima social anticiência de ambos os lados do espectro de opinião. A ampla cobertura dos meios de comunicação a respeito das recentes controvérsias relativas à epidemia BSE/CJD e sobre os alimentos geneticamente modificados contribuíram significativamente para criar um clima de 
considerável tensão nas relações entre Ciência e Sociedade (Dora, Bauer, e Millstone, 2006). O lobby pró-PCTE a proveitou para explicar as ansiedades sociais na PCTE causadas por esta tensão mais ampla e para desacreditar os seus opositores, caracterizados como "desinformados" e movidos por "um pânico moral". Desenvolveu um ativo lobbying para contradizer os efeitos desse mal-estar social.

O debate Parlamentar foi dominado novamente por numerosas considerações a respeito "da questão do embrião" (Franklin, 1999). Além disso, as estratégias políticas diferentes dos grupos defensores e opositores à PCTE foram muito semelhantes àquelas usadas no contexto da aprovação da Ata do HFEA de 1990. Neste momento, o grupo defensor mostrou-se muito mais bem articulado e mais ativo do que antes. Reclamou das tentativas de sabotar o financiamento, o trabalho e os esforços anteriores efetuados nas áreas de embriologia, desenvolvimento celular e pesquisa genética. Considerou a totalidade do campo da biotecnologia como "ainda em perigo" (Mulkay, 1997:26). Os grupos opositores, em contestação, mobilizaram a retórica dos direitos humanos no contexto de "uma ciência fora de controle".

O grupo pró-PCTE sustentou, como estratégia retórica, que a PCT não diferiria da pesquisa vinculada à fertilização assistida. Demarcou a discussão das CT dentro da totalidade da pesquisa com embriões e do seu uso no limite dos 14 dias permitido pela Ata de 1990 e considerado fato biológico. Também enfatizou o status especial do embrião, segundo o já estabelecido no Informe Warnock (1985). O uso de embriões em pesquisa foi naturalizado e o campo opositor foi acusado de irracional. No decorrer do debate, foi modificado o significado atribuído à pesquisa associada à fertilização assistida: de um "experimento em seres humanos desamparados" passou a "pesquisa com materiais biológicos não formados" ou, a uma "pequena coleção de células" (Parry, 2003:185). Delimitou-se, então, como enclosure técnico-científico, um terreno onde debates sociais, legais e morais mais amplos no desenvolvimento das técnicas de clonagem foram excluídos, como, por exemplo, aqueles sobre as implicações socioculturais destas tecnologias para as relações de parentesco e para as desigualdades na saúde.

Outro aspecto importante durante o debate foi o recrutamento de grupos de potenciais usuários dessas terapias, um fato crucial no sucesso do lobby pró-pesquisa. Os parlamentares articularam a demanda desses grupos com base em narrativas de esperança e medo e na premissa do 
desespero das pessoas doentes, que ajuda a naturalizar a PCT, no entanto ela se encarna na sequência narrativa da vida. Recorre-se, então, à Ciência e à Tecnologia para estabelecer "uma ponte" no momento em que a "progressão natural da vida" é alterada por infertilidade ou doença (Franklin, 1997:94).

Uma terceira estratégia utilizada durante o debate pelos grupos própesquisa consistiu em referenciar o mesmo dentro da etapa atual do desenvolvimento científico nacional e da carreira biotecnológica do país. Este grupo argumentou que a reforma da Lei contribuiria para um reposicionamento da biotecnologia nacional na economia, para um alívio da carga do sistema de saúde e para a transformação dos cientistas da PCT em líderes mundiais, em suas respectivas especialidades (Parry, 2003).

\section{POLÍTICAS PÚBLICAS RECENTES PARA PCTE NO REINO UNIDO}

No período entre 2001 e 2008, procurou-se um maior engajamento social e a participação de um público mais amplo, em eventos e discussões sobre a PCTE, num clima de diálogo, segundo o definido pela Royal Society. Em seguida, houve duas novas mudanças na política pública da área: uma em 2006 e a outra aprovada em 2008. Embora apenas a última tenha dado lugar a um novo debate Parlamentar.

Em 2006, a HFEA decidiu rever a Ata para acompanhar as transformações tecnológicas, incluindo cláusulas da Diretiva Europeia de Tecidos e Células (European Parliament and Council of the European Union, 2004) e resolver problemas de jurisdição entre duas agências reguladoras diferentes: a Autoridade Britânica de Tecidos e a HFEA. Esta revisão modificou a regulamentação sobre o uso de embriões excedentes da fertilização assistida em pesquisa e aceitou a criação de embriões especificamente para pesquisa, utilizando a técnica de SCNT (stem cell nuclear transfer ou clonagem terapêutica). Regulamentou duas fontes principais de óvulos com esta finalidade: aqueles extraídos, segundo o programa de egg-sharing, das mulheres pacientes da fertilização assistida ${ }^{16}$ e aqueles obtidos por doação voluntária ${ }^{17}$.

Esta iniciativa se enquadra na revisão periódica de critérios de licenciamento da HFEA e surge a partir da solicitação, por um grupo universitário, de uma licença de pesquisa que utilizava a técnica de clonagem terapêutica. No ano de 2006, um novo pedido de licença, neste momento para a clonagem terapêutica de embriões mistos (animais/huma- 
nos), requer que o governo se posicione. Foi encomendado um relatório - o White Paper - que, sendo contrário à criação in-vitro de embriões mistos, dá início a uma série de novos debates sociais e parlamentares. Inicialmente, o governo propõe proibir a maioria dos tipos de embriões trans-espécies criados para pesquisa. Mais tarde, o governo, pressionado pelo JCHTE (o Comitê Conjunto das Câmaras de Lordes e de Comuns sobre o Anteprojeto de Lei de Tecidos Humanos e Embriologia), um Fórum criado para a discussão, reverteu sua posição (JCHTE, 2007a). A Lei final, aprovada pelo Parlamento em novembro de 2008, modificou, ainda mais radicalmente, a política pública vigente para a pesquisa com embriões. Permitiu a clonagem para pesquisa de todos os tipos de embriões híbridos interespécies existentes, mediante licença com cinco tipos de categorias diferentes. Em abril do ano de 2008, foi anunciada a primeira clonagem local desse tipo de embrião para fins de pesquisa.

Os debates tentaram dirimir dois tipos de tensões. A primeira fazia alusão a uma ambiguidade na Lei inicial de 1990, que, simultaneamente, proibia e permitia a criação de espécies híbridas (animais/humanas). A lei aceitava um diagnóstico clínico para a (in)fertilidade masculina o hamster test, que resulta na criação de um embrião híbrido (ainda que ele tenha de ser descartado, por lei, na fase mais recente não superior a duas células e seja inviável para a gestação). A segunda relacionava-se com diferentes posições a respeito da diferenciação de organismos interespécies. Estas duas estratégias provocaram uma divergência ou uma ambivalência nas posições apresentadas, segundo a polaridade "diferenciação técnica versus igualdade moral" (Brown, 2009).

Ainda que, inicialmente, o governo tivesse tentado estabelecer distinções na classificação de embriões derivados de técnicas fundamentalmente diferentes, uma maioria na comunidade científica argumentou que os embriões trans-espécies não deveriam, em princípio, ser tratados como diferentes entre si. Sendo todos igualmente híbridos, todos deveriam ser permitidos.

Os formuladores de políticas se perguntaram se estes cíbridos poderiam ser considerados também como hibridos da ordem animal, proibidos pela legislação vigente e regulamentados por outra jurisdição, o Home Office. Alternativamente, eles poderiam ser considerados humanos, o que era legalmente permitido pela HFEA, como pré-embriões para pesquisa (HFEA, 2006). Ao tentar proibir o embrião trans-espé- 
cies, qualificando-o como mais especial que os embriões humanos, paradoxalmente, se outorgava uma maior proteção a não-humanos, desrespeitando a hierarquia do humano em relação a outras espécies (JCHTE, 2007b).

Outro tema problemático foi o da distinção moral desenvolvida durante o debate entre tipos de embriões trans-espécies produzidos por diferentes técnicas. Foi discutido se eram híbridos ou quimeras ou outra coisa, e as definições foram paulatinamente mais flexíveis (Parry, 2010). Depois de uma deliberação extensa, foi determinado que os cíbridos fossem considerados essencialmente humanos e, como tal, estariam sujeitos à legislação vigente e as suas instituições ${ }^{18}$.

Esta interpretação dos cíbridos ${ }^{19}$ foi baseada na perspectiva, predominante durante o debate, de que o ADN mitocondrial hereditário do óvulo animal seria insignificante para determinar os atributos da espécie no embrião resultante. No entanto, o ADN nuclear definiria legalmente a espécie humana, visão convergente com a maioria das posições. Muitos autores questionam a veracidade, tanto em uma visão engenerada da definição dessa relação dentro da célula: uma hierarquização do núcleo masculino celular sobre a periferia feminina (Haraway, 1995; M'Charek, 2005).

A forma de definição da identidade dos embriões interespécies, por sua vez, é de grande relevância para o estabelecimento de jurisdições claras entre diferentes agências reguladoras. O legado histórico da ordem regulatória atual complica a governança simultânea de organismos trans-espécies e trans-institucionais, desafiando as fronteiras normativas tradicionais entre espécies e entre instituições (Brown et alii, 2006). As mudanças observadas também questionam alguns dos princípios e ordens epistemológicas tradicionais da Ciência sobre diferenciação, taxonomia e distinção (Brown, 2009). Contudo, os conteúdos e a forma do debate parlamentar mostram que a criação de organismos interespécies não leva a um total abandono da visão hierárquica - do tipo humanista - entre as espécies e do privilégio do humano versus uma possível erosão cultural das fronteiras entre espécies.

\section{ALGUMAS COMPARAÇÕES ENTRE OS DEBATES NO BRASIL E NO REINO UNIDO}

Existem algumas divergências e convergências centrais entre os debates brasileiros e britânicos, segundo as culturas políticas em que se in- 
serem. As mesmas serão analisadas no contexto deste breve artigo, em relação a quatro aspectos principais que se relacionam à potencial coprodução científica e social da PCT e a sua compreensão por um público que inclui especialistas e leigos: as propostas de políticas públicas e legislativas; a construção técnico-científica e moral dos discursos; o papel atribuído à sociedade civil; e a inserção global de cada país em genética e biotecnologia ${ }^{20}$.

Com relação ao primeiro aspecto, uma divergência importante refere-se à qualidade e quantidade de sistematização das políticas públicas na área, do marco regulatório e das legislações associadas. No Brasil, a discussão sobre CT é relativamente recente e não se enquadra numa reformulação estruturada do conjunto das práticas e pesquisas em reprodução e genética humana, como no caso britânico. A falta de centralização das políticas numa agência brasileira especializada contribui para que sua regulamentação discuta, por exemplo, os cultivos transgênicos, e para que, atualmente, o controle institucional para alguns dos ensaios clínicos em terapia celular (Fase I) seja um tanto errático.

A delimitação de fronteiras institucionais regulatórias se torna mais complexa num campo emergente e em expansão, instalando-se certa urgência para a discussão de novos temas e padrões de regulamentação pertinentes. Incertezas, o ritmo do progresso científico e as mudanças nas estratégias tecnológicas associadas, frequentemente, afetam este campo do conhecimento, gerando certa instabilidade nos marcos regulatórios. Essas características do setor dificultam também a criação de políticas transparentes, dinâmicas, flexíveis e participativas. Apesar de os conteúdos do debate nos países serem consideravelmente diferentes, ambos os casos convergem numa dificuldade de estabelecer fronteiras regulatórias adequadas, necessárias para a gestão dentro de instituições regulatórias pertinentes, a objetos de pesquisa que desafiam as regras e os padrões tradicionais.

Em ambos os países, os debates transformaram-se em instrumentos muito relevantes para a criação e/ou a reforma legislativa e para a implementação de controles imediatos e de fiscalização da PCT. Tanto para Parlamentares como Congressistas, o debate representou um reconhecido meio de esclarecimento de muitos aspectos da PCT, transformou a hostilidade inicial numa liberação condicional da PCTE e 
tem contribuído para regular as práticas que devem ser proibidas e/ou mais estreitamente controladas.

Contudo, apesar dessas convergências, existem importantes divergências, em forma e estilo, entre os marcos regulatórios aprovados. Enquanto, no Brasil, a legislação manteve-se incipiente e amalgamando temas de diferente natureza, no Reino Unido, se estabeleceu uma estrutura legislativa sólida e coerente, desenvolvida gradualmente durante duas décadas, baseada num objeto legislativo próprio, caracterizado de modo específico e gerenciado por uma agência específica. Os controles estabelecidos na lei brasileira se limitaram, basicamente, aos tipos de embriões para utilização em pesquisa.

Com relação ao segundo aspecto, a construção de retórica e discursos, os debates convergem no que se refere apenas a alguns aspectos do conteúdo, dado o papel preponderante que ocupa a questão do embrião na retórica interpretativa usada. Porém, esta mesma discussão está sujeita a certas nuances socioculturais por país. Por exemplo, a posição pragmática prevalecente no campo da defesa da PCTE baseia-se em discussões e posições ontológicas mais claramente demarcadas no Reino Unido do que no Brasil. Além disso, a gradação hierárquica entre tipos de embriões humanos (e interespécies) aparece como um eixo polêmico mais frequente, no interior de ambos os campos, defensores e opositores, no Reino Unido do que no Brasil. A visão dominante britânica reflete o caráter dividido atribuído à determinação de fatos biológicos versus a sua interpretação ético/social, estudada por vários autores. A forma assumida por esta divisão denuncia uma mudança paradigmática hegemônica: uma transição, a partir da perspectiva que conceitua o embrião como unidade inicial de vida humana, para aquela que considera a CTE como tal. No caso brasileiro, pelo contrário, só se encontram algumas referências esporádicas de tal alteração. O grupo defensor, neste país, articula menos sistematicamente suas explorações de fatos biológicos, de marcos éticos e de referências ontológicas e, às vezes, justapõe e articula, no mesmo discurso, aspectos correspondentes a diferentes aproximações ontológicas ou religiosas/morais/éticas sobre o início da vida e/ou da vida humana ${ }^{21}$. No entanto, em ambos os debates, o utilitarismo das perspectivas dominantes fundamenta-se, de forma convergente, no serviço potencial dos embriões extracorpóreos à "sociedade ou a outros concretos", estes últimos representados de forma testemunhal, presencial e visual. 
Porém, as questões concretas abordadas em cada debate nacional diferem significativamente. Por exemplo, no caso do Brasil, a diferenciação entre clonagem terapêutica e reprodução humana não constitui um eixo discursivo e a primeira não aparece como tema do debate, diferentemente do caso britânico, no qual esses eixos dominam a reforma da Lei do ano 2001. Além disso, a polêmica sobre embriões trans-espécies, crucial no Reino Unido durante os anos 2007 e 2008, está ausente da discussão brasileira. A explicação de tais diferenças não pode ser reduzida às temáticas específicas presentes nas respectivas legislações. Está nas representações sociais e culturais dominantes e nas estratégias de gestão e negociação de perspectivas durante os debates, principalmente, dentro dos blocos defensores da pesquisa.

O progresso técnico também é representado com retóricas divergentes por país, embora em ambos os casos constitua, até certo ponto, um saber com autoridade. No Brasil, a construção do discurso reflete crenças culturais mais uniformemente enraizadas sobre "a inevitabilidade e a fé", na direção do progresso técnico-científico. No Reino Unido, vislumbra-se um questionamento social mais abrangente da relação Ciência-Sociedade, refletindo a crise de objetividade que permeia diferentes setores dessa sociedade. No decorrer de ambos os debates, se naturalizam e normalizam algumas das práticas de PCTE que, no começo, geraram resistência. Mas, apenas no caso britânico, estas tendem a originar um novo vocabulário de referência, que contribui substantivamente para produzir momentos de inflexão no debate.

As formas, táticas e estratégias usadas para a construção de novas fronteiras na área também divergem significativamente entre países. Enquanto, no Brasil, a delimitação Ciência-não Ciência e Boa Ciência-Má Ciência ocupa um lugar privilegiado na polêmica, fundamentando-se em abundantes referências às praticas internacionais, o debate britânico centra-se na busca de uma coerência entre níveis conceituais técnico-científicos e éticos e modificam-se os termos usados ou são criados novos conceitos, por exemplo, os de pré-embriões, cíbridos, embriões humanos mistos.

Também divergem significativamente as estratégias organizacionais dos debates. Um aspecto que se destaca no debate brasileiro é o desestímulo e a proibição da confrontação de idéias, refletindo, provavelmente, um temor cultural mais amplo (ver, por exemplo, Damatta e Hess, 1995). O diálogo é promovido pelos britânicos e é caracterizado por 
uma busca de compromisso e negociação entre posições opostas. Inclusive, frequentemente, os argumentos da oposição são integrados dentro do próprio argumento.

A politização do aspecto ético da controvérsia caracteriza ambos os debates. A moralidade é usada como último recurso e polarizada entre: "o embrião versus as pessoas que sofrem ou os pacientes de ensaios clínicos", "o embrião versus os familiares dos pacientes", "o embrião versus a responsabilidade dos cientistas". Os pacientes potenciais são representados como desesperados. Omite-se, por exemplo, as várias reivindicações de organizações britânicas de pacientes ou pacientes individuais, nesse país, que defendem sua condição de incapacidade ou de privação sensorial e anseiam transmiti-la a seus descendentes.

Com relação ao terceiro aspecto, as formas de inclusão do público ou dos públicos, as diferenças são substantivas entre os países, apesar de se observarem algumas características comuns. Como parte do modelo neoliberal adotado e seus efeitos em detrimento das identidades sociais, em ambos os países, por um lado, desconstroem-se as doenças como públicas, e, por outro, recorre-se à saúde pública como modelo de sustentação e argumentação a favor das novas terapias celulares (Cesarino, 2007). Ambos os lobbies nos dois países pretendem integrar aos públicos como recurso (pacientes e familiares no lobby defensor; grupos antiaborto e religiosos no lobby opositor), através de uma estratégia de hype e hope.

Porém, a motivação, a classe, a intensidade, a duração e a organização estruturada da participação diferem diametralmente entre os países, assim como os estilos de participação pública mais ampla. A participação oficial e pública britânica é top down e bottom up, de caráter massivo e complementa-se com a desenvolvida por numerosas associações britânicas privadas altamente influentes. No Brasil, diferentemente do caso britânico, a campanha usa estratégias de lobbying, ação temporária e de alto tom emocional e não um processo de participação decisória. A participação brasileira tende a ser pontual, destinada a eventos específicos, principalmente convocados pela própria comunidade científica ou por lobbystas influentes; a participação bottom up é desencorajada e carece de uma organização sólida, que perdure no tempo, e de seus próprios meios estáveis de difusão.

As organizações de pacientes brasileiros, mesmo quando articuladas dentro do lobby defensor, por exemplo, são menores e menos ativas no 
debate público e contam com uma menor interligação entre elas que no caso britânico. A forma da inclusão dos públicos fundamenta-se num modelo de déficit, top-down, ou seja, de educação e treinamento da sociedade civil a partir do Estado ou do establishment científico (Irwin e Wynne, 1996). O papel do conhecimento leigo e experimental e as vozes de outros setores sociais de opinião (por exemplo, do movimento de mulheres, de afro-brasileiros, de indígenas, de associações de consumidores e de ONGs de saúde, entre outros) são silenciados, principalmente, durante os debates públicos (Fonseca, 2008). O caso mais relevante talvez seja a omissão das vozes dos doadores potenciais, um fato convergente nos debates de ambos os países.

O Brasil, mesmo levando-se em consideração as consultas públicas seletivas a stakeholders, carece de um esquema apropriado de consultas públicas estáveis e diálogos periódicos para esta área que realmente envolvam diferentes setores de opinião. Mais ainda, algumas destas atividades parecem se desenvolver dentro de um marco clientelista (Pereira de Farias, 2010). Os públicos brasileiros são engajados nesses debates de modos já estudados para outras dimensões da prática social local ${ }^{22}$ que denunciam tentativas de transição entre o exercício de uma democracia representativa, por uma parte, e o de uma democracia direta e participativa, por outra.

A inserção global de cada país em genética e biotecnologia diverge de fato significativamente. Contudo, certas narrativas convergentes utilizam-se nos debates para descrever as respectivas estratégias para PCT. Nos sucessivos períodos das controvérsias, as referências à competitividade internacional em biotecnologia e/ou em genética, em cada país, são construídas como recursos para a aceitação do progresso científico. As terapias potenciais são medidas em relação a sua utilidade no futuro, tanto para o tratamento de doenças, como para a competitividade de cada um dos países. Existem, porém, algumas diferenças entre estas confluências de perspectivas. Enquanto o Reino Unido se considera um líder mundial, com dúvidas e temores de perda da sua posição em biotecnologia e genética, o Brasil considera esta área uma nova oportunidade de inserção internacional. $\mathrm{O}$ debate brasileiro enfatiza as consequências negativas de "ficar para trás", entretanto a atualização do Brasil, em comparação a outros países, é apresentada desde um certo hype, especialmente ao descrever a evolução da terapia local com CTA. 
O debate também é construído convergentemente a partir de uma grande omissão: a da comercialização e distribuição destas eventuais terapias (Franklin e Kaftantzi, 2008). Portanto, as controvérsias obscurecem a relação com as empresas de biotecnologia nacionais e internacionais.

(Recebido para publicação em maio de 2010)

(Versão definitiva em novembro de 2010)

\section{NOTAS}

1. Para o Brasil, utilizou-se na análise, principalmente: a) para o caso da ADI (3510), transcrições das apresentações dos cientistas e ministros do STF; b) publicações acadêmicas anteriores (Cesarino, 2007; Scavone, 2008; Tait Lima, 2009); c) resultados parciais de entrevistas de um projeto de pesquisa em curso e, de modo secundário, d) material jornalístico. Para o Reino Unido, utilizou-se, principalmente: a) textos acadêmicos de análises anteriores (entre eles, Franklin, 1999; Mulkay, 1997; 1993; Brown, 2009; Acero, no prelo), e, secundariamente, b) informes do Joint Committee on the Human Tissue and Embryos [Draft] Bill (JCHTE) (2007a, 2007b) e elementos conceituais da análise de debates de temáticas afins em outros contextos (ver, por exemplo, Herold, 2007).

2. Em 1998, os cientistas americanos James Thompson e John D. Gearhart teriam conseguido isolar e cultivar linhagens de células-tronco embrionárias (CTE), o que prometia uma rápida expansão mundial deste campo científico.

3. Cientistas e lideranças da sociedade civil entrevistados comentam a excessiva demanda dos doentes para serem incluídos em ensaios clínicos destas terapias, assim como sua falta de informação a respeito das possibilidades reais de tratamento e cura, e relatam também alguns conflitos suscitados pelas expectativas de cura geradas (Acero, no prelo).

4. Refere-se ao fato de que prometem-se benefícios exagerados e o desenvolvimento de terapias em curto prazo, e isso aumenta demais a esperança dos pacientes na cura.

5. No entanto, alguns dos cientistas consideraram que a convocatória de representantes foi muito centralizada e que a composição dos blocos foi claramente desigual (Scavone, 2008; Acero, no prelo).

6. Houve uma presença muito limitada dos Ministros do STF à Audiência Pública, fato questionado pela comunidade científica e pelo público, em geral. De um total de 11 Ministros, apenas 4 estiveram presentes e um participou a distância. Presume-se que os demais assistiram as transmissões diretas pela TV e Rádio Justiça.

7. Com este termo Jasanoff (2005:127) define as múltiplas formas nas quais o conhecimento é produzido, apresentado, testado, verificado e utilizado no domínio público; 
conhecimento que é contextual e histórico e varia segundo os estilos dominantes de gerar conhecimento público, os métodos para dar transparência às políticas públicas; as práticas de demonstração pública; as definições sociais acerca da objetividade do conhecimento e as formas de reconhecimento e aceitação social do conhecimento especializado.

8. A referência de centralização bioética, no caso da PCT - a diferença das novas tecnologias reprodutivas com um controle bioético mais descentralizado (Fonseca, 2008) -, refere-se ao papel de instituições como o Conselho Nacional de Ética em Pesquisa (Conep), para fixar as linhas bioéticas gerais, e da Agência Nacional de Vigilância Sanitária (Anvisa), como fiscalizadora de algumas práticas na área, por exemplo, o cadastro de embriões excedentes para reprodução e pesquisa (sistema SisEmbrio). A descentralização referida se relaciona à flexibilidade no papel dos Comitês de Ética em Pesquisa (CEPs) nas diferentes instituições para a implementação prática das linhas bioéticas gerais e ao papel das associações especializadas nesta área de pesquisa, como a Rede de Terapia Celular, na interpretação dos princípios bioéticos que guiam a formulação dos ensaios clínicos.

9. Distingue-se, com esta noção, o pré-embrião do embrião propriamente dito pela formação inicial da linha primitiva aos 14 dias de desenvolvimento.

10. Baseado nas relações sociais de gênero.

11. Na atualidade se redefinem posições similares dentro do debate nacional atual sobre liberalização do aborto anencefálico.

12. Delineada pela II Conferência de Ciência, Tecnologia e Inovação em Saúde de 2004, com a devida articulação entre os Ministérios de Ciência e Tecnologia, da Saúde e da Indústria e Comércio e com o trabalho de suporte da Conep.

13. Especialmente neste aspecto, já que a diversidade étnico-racial de linhagens de CTE seria fundamental para o êxito da pesquisa e das terapias, nesta área, o Brasil teria uma vantagem neste sentido, tendo em conta a diversidade étnico-racial da sua população.

14. A Ata teve como principais objetivos: a criação de um marco regulatório para o controle, a supervisão da pesquisa com embriões e de pautas para o licenciamento da fertilização assistida e a reforma da Lei do Aborto de 1967.

15. Em 1996, foram introduzidas modificações na Ata. Pediu-se aos casais o consentimento livre e esclarecido por escrito para o armazenamento de embriões por mais de 10 anos e propôs-se oficialmente o descarte dos embriões cujos pais não fora possível localizar. O descarte desses milhares de embriões foi acompanhado de um escândalo público.

16. Egg-sharing, processo pelo qual as pacientes em fertilização assistida doam alguns dos seus óvulos para pesquisa em troca de reduções nos custos de seus tratamentos.

17. Este último debate parlamentar desenvolveu- se quando, no Reino Unido, existia uma relativa escassez de óvulos para pesquisa: só um terço dos óvulos obtidos por fertilização assistida era utilizado para pesquisa no programa de egg-sharing e as doações voluntárias - embora tenham se duplicado no período 1992-2008 - representavam um total de apenas 1,084 óvulos (HFEA, Donor Statistics, 1992-2008; disponível em http:/ / www.hfea.gov.uk. Acessado em 4/4/2010.

18. O HFEA convocou uma segunda consulta pública mais ampla que a primeira, entre abril e julho de 2007, cujos resultados interpretaram como: de apoio do público à pes- 
quisa com embriões trans-espécies. A consulta foi efetuada somente depois de terem sido tomadas as suas decisões.

19. Em 1998, Advanced Cell Technology tinha anunciado a criação de um embrião usando um óvulo de vaca e um núcleo humano de uma célula extraída da bochecha de um de seus próprios cientistas. Em 1999, uma patente de processos com a criação de embriões interespécies para toda a Europa (EP 380646) tinha sido outorgada à empresa australiana Amrad. Em 2003, a imprensa internacional informou sobre estudos em outros países, entre eles a China, com embriões interespécies para pesquisa, com a utilização de óvulos de coelhos.

20. Ver Acero (no prelo) para uma discussão e comparação mais abrangente.

21. Ver Cesarino (2007, Quadro 1) para uma classificação de cinco teses diferenciadas sobre o início da vida humana presentes no domínio público brasileiro: genética, embriológica, neurológica, ecológica e gradualista.

22. Para uma análise de outras práticas sociais, ver, por exemplo, Gerschman e Vianna (1997). 


\section{REFERÊNCIAS BIBLIOGRÁFICAS}

ACERO, Liliana. (2007), “Genetics and Gender: New Reproductive Technologies in Latin America", in P. Atkinson; A. Glasner e H. Greenslade (eds.), New Genetics, New Identities. London, Routledge.

. (no prelo), Pesquisas com Células-Tronco e Terapias Celulares: Governança, Visões Sociais e o Debate no Brasil. Rio de Janeiro, e-Papers.

BROWN, Nik. (2008), "Beasting the Embryo: The Metrics of Humanness in the Transpecies Embryo Debate". BioSocieties, vol. 14, no 2-3, pp. 147-163.

CESARINO, Letícia da N. (2007), “Nas Fronteiras do Humano: Os Debates Britânico e Brasileiro sobre Pesquisa com Embriões. MANA, vol. 13, no 2, pp. 347-380.

CORRÊA, Marilena Cordeiro D. Villela. (2001), “Ética e Reprodução Assistida. A Medicalização do Desejo de Filhos". Bioética, vol. 9, no 2, pp. 71-82.

DAMATTA, Roberto e HESS, David. (orgs.). (1995), The Brazilian Puzzle: Culture on the Borderlands of the Western World. New York, Columbia University Press.

DINIZ, Debora e AVELINO, Daniel. (2009), “Escenario Internacional de la Investigación en Células Madre Embrionárias". Revista de Saúde Pública, vol. 43, no3, pp. 541-547.

e GOMES COSTA, Rosely. (2007), “Infertilidade e Infecundidade: Acesso às Novas Tecnologias Conceptivas", in V. Ferreira; M. B. Ávila e A. P. Portella (orgs.), Feminismo e Novas Tecnologias Reprodutivas. Recife, Edições SOS Corpo.

DORA, Carlos, BAUER, Martin e MILLSTONE, Erik. (2006), Health, Hazards and Public Debate: Lessons for Risk Communication from the BSE/CJD Saga. Copenhagen, World Health Organization.

EUROPEAN PARLIAMENT e COUNCIL OF THE EUROPEAN UNION. (2004), “Tissue and Cell Directive. Directive 2004/23/EC of 31 March 2004". Official Journal of the European Union, Bruxelas, União Europeia.

FERREIRA, Verônica, ÁVILA, Maria Betânia e PORTELLA, Ana Paula (orgs.). (2007), Feminismo e Novas Tecnologias Reprodutivas. Recife, Edições SOS Corpo.

FONSECA, Claudia. (2008), “A Participação Leiga nos Rumos da Ciência: De Embriões a Maternidade Assistida”. Saúde e Direitos Humanos, ano 5, no 5, pp. 127-142.

FRANKLIN, Sarah. (1997), Embodied Progress: A Cultural Account of Assisted Conception. London, Routledge.

(1999), “Making Representations: The Parliamentary Debate on the Human Fertilisation and Embryology Act", in J. Edwards et alii (eds.), Technologies of Procreation: Kinship in the Age of Assisted Conception (2a ed.). London, Routledge.

e KAFTANTZI, Lamprini. (2008), "Industry in the Middle: Interview with Intercytex Founder and CSO, Dr. Paul Kemp". Science as Culture, vol. 17, no 4, pp. 449-462.

FRANKLIN, Sarah, LURY, Celia e STACEY, Jackie (eds.). (2000), Global Nature, Global Culture. London, Sage.

GERSCHMAN, Silvia e VIANNA, Maria L. T. Werneck (1997), AMiragem da Pós-Modernidade: Democracia e Politicas Sociais no Contexto da Globalização. Rio de Janeiro, Fiocruz. 


\section{Ciência, Políticas Públicas e Inclusão Social: Debates sobre Células-Tronco...}

HARAWAY, Donna J. (1997), ModestãWitness@SecondãMillennium. FemaleMan@ ãMeetsãOncoMouse ${ }^{\mathrm{TM}}$. London, Routledge.

HEROLD, Eve. (2007), Stem Cell Wars: Inside Stories from the Frontline. London, Palgrave MacMillan.

HFEA (Human Fertilisation and Embryology Authority). (2001), Code of Practice (5a ed.). Disponível em http://www.hfea.gov.uk/code2001/cop2001/pdf. Acessado em abril de 2010.

. (2006), Donating Eggs for Research: Safeguarding Donors. London, HFEA.

HGAC (Human Genetics Advisory Commission) e HFEA (Human Fertilisation and Embryology Authority). (2008), Cloning Issues in Reproduction, Science and Medicine. Disponível em http://www.dti.gov.uk/hgac/papers/paperc1.html. Acessado em abril de 2010.

IRWIN, Alan e WYNNE, Brian. (1996), "Introduction", in A. Irwin e B. Wynne (eds.), Misunderstanding Science? The Public Reconstruction of Science and Technology. Cambridge, Cambridge University Press.

JCHTE (Joint Committee on the Human Tissue and Embryos). (2007a), Human Tissue and Embryos (Draft) Bill. London, The Stationery Office, vol. I.

_ (2007b), Human Tissue and Embryos (Draft) Bill. London, The Stationery Office, vol. II.

JASANOFF, Sheila. (2004), States of Knowledge: The Co-production of Science and Social Order. New York, Routledge.

. (2005), Designs on Nature: Science and Democracy in England and the United States. Princenton, Princeton University Press.

LATOUR, Bruno e WOOLGAR, Steve. (1978), Laboratory Life: The Social Construction of Scientific Facts. London, Sage.

LUNA, Naara. (2007a), “Células-Ttronco: Pesquisa Básica em Saúde, da Ética a Panacéia". Interface: Comunicação, Saúde, Educação, vol. 11, no 23, pp. 587-604.

(2007b), "A Personalização do Embrião Humano. Da Transcendência na Biologia". MANA, vol. 13, no 2, pp. 411-440.

. (2008), "Religiosidade no Contexto das Terapias com Células-Tronco: Uma Investigação Comparativa entre Pesquisadores 'Iniciantes e Iniciados' e seus Pacientes". Religião e Sociedade, vol. 28, no 2, pp. 156-178.

MARTIN, Paul, BROWN, Nik e TURNER, Andrew. (2008), “Capitalizing Hope: The Commercial Development of Umbilical Cord Blood Stem Cell Banking". New Genetics and Society, vol. 27, no 2, pp. 127-143.

M'CHAREK, Amade. (2005), "The Mitochondrial Eve of Modern Genetics: Of Peoples and Genomes, or the Routinization of Race". Science as Culture, vol. 14, no 2, pp. 161-183.

MULKAY, Michael. (1993), "Rhetorics of Hope and Fear in the Great Embryo Debate". Social Studies of Science, vol. 23, no 4, pp. 721-742.

(1997), The Embryo Research Debate: Science and the Politics of Reproduction. Cambridge, Cambridge University Press. 
PARRY, Sarah. (2003), "The Politics of Cloning: Mapping the Rhetorical Convergence of Embryos and Stem Cells in Parliamentary Debates". New Genetics and Society, vol. 22, no pp. 177-200.

. (2006), "(Re)constructing Embryos in Stem Cell Research: Exploring the Meanings of Embryos for People Involved in Fertility Treatment". Social Science of Medicine, vol. 62, no 10, pp. 2349-2359.

. (2010), "Interspecies Entities and the Politics of Nature", in S. Parry e J. Dupré (eds.), Nature After The Genome. Oxford, Blackwell.

PEREIRA DE FARIAS, Francisco. (2010), “Coronelismo, Clientelismo e a Política de Direita". Le Monde Diplomatique-Brasil, vol. 3, no 34, p. 8.

SCAVONE, Rafael Bellem de L. (2008), Audiência Pública Realizada na ADI 3510-0: A Organização e o Aproveitamento da Primeira Audiência Pública da História do Supremo Tribunal Federal. Trabalho de conclusão do curso, Escola de Formação, Sociedade Brasileira de Direito Público, São Paulo.

STF (Supremo Tribunal Federal). (2008), Transcrições da Audiência Pública da Ação de Inconstitucionalidade (TAP-ADI) (3510-0). STF em Foco. Disponível em http:/ / www.stfemfoco.org.br. Acessado em março de 2010.

. (2008b), Votos dos Ministros do Supremo Tribunal Federal. Seção Notícias. Disponível em http:/ / www.jus.br. Acessado em março de 2010.

TAIT LIMA, Marcia M. (2009), As Concepções dos Cientistas Brasileiros sobre a Tecnociência: Um Estudo a partir da CTNBio. Dissertação de Mestrado, Instituto de Geociências, Universidade Estadual de Campinas, Campinas.

WARNOCK, Mary. (1985), A Question of Life: The Warnock Report on Human Fertilisation and Embryology. Oxford, Blackwell. 


\section{ABSTRACT \\ Science, Public Policies, and Social Inclusion: The Stem Cell Debate in Brazil and the United Kingdom}

This article analyzes the main rhetorical approaches, themes, and strategies in the contemporary public debate on stem cell research and therapies in Brazil. Based on previous studies, analysis of the transcripts from public hearings, newspaper clippings, and 15 semi-structured interviews with researchers, public policymakers, and representatives of organized civil society, the article discusses divergences and convergences between the proponents and opponents of such research. The results are compared to trends in the United Kingdom, a leading country in the field, concluding that the main difference between the two countries lies in the form of social inclusion and public participation.

Key words: stem cell research; public policies; embryonic cells; public debate; public participation; social inclusion; biotechnology

\section{RÉSUMÉ}

Science, Politiques d'État et Inclusion Sociale: Débats sur les Cellules Souches au Brésil et au Royaume Uni

Dans cet article, on examine quelques recours rhétoriques, thèmes et stratégies mis en oeuvre pendant les débats publics actuels au Brésil, concernant la recherche sur les cellules souches et les thérapies cellulaires. À partir de travaux universitaires antérieurs, de l'analyse de transcriptions d'audiences publiques et d'articles de presse ainsi que de 15 entretiens semi-structurés avec des chercheurs, des agents de politiques publiques et des représentants de la société civile au Brésil, on évalue les divergences et convergences entre les défenseurs et opposants de ces recherches. On termine sur une réflexion comparative de controverses choisies au Brésil et au Royaume Uni - ce dernier étant pionnier dans ce domaine et dans sa réglementation -, par rapport à des propositions de politiques publiques, une construction technique, scientifique et morale des discours, un rôle de participation de la société civile et l'insertion globale des pays en génétique et biotechnologie. On en conclut que les plus grandes divergences reposent sur les formes d'inclusion et l'engagement du public.

Mots-clés: recherches sur des cellules souches; politiques publiques; cellules embryonnaires; débat public; participation publique; inclusion sociale; biotechnologie 